\title{
Impact Of Supply Chain Integration On Business Performance And Its Challenges
}

Abdullah AlSagheer, Hamdan Bin Mohammed e-University, Dubai, UAE Maryam Ahli, Etihad Airways, Abu Dhabi, UAE

\begin{abstract}
The basic objective of this paper is to analyze the impact of supply chain integration on business performance and the challenges associated with supply chain integration. This paper selects different research papers and articles to present the empirical evidence regarding supply chain integration, its impact on business performance and the challenges associated with it. A sample of 21 research papers was selected in the analysis/findings section and discussion section to discuss the impact of supply chain integration on business performance and the challenges associated with the integration of supply chain among different channel partners. The time period of 1995 2011 was selected and only those journal articles/research papers were selected that were published within this period. Different research papers provided an empirical proof that supply chain integration led to better business performance but few of them discussed challenges associated with it. There was only one paper of Awad \& Nassar (2010b) that prominently addressed those challenges. This identified a research gap to be filled and weakened the argument that supply chain leaded to better business performance because how it could be argued when the business challenges associated with supply chain integration were not analyzed and assessed efficiently in the previous research. The author also researched and found papers that held an opposite view regarding supply chain integration. Therefore, more empirical research was proposed and advised to be conducted in this area and it was concluded that further research was crucial to understand the importance of supply chain integration, its impact on business performance and its challenges. As for limitations, it was a secondary research that was one of the main research limitations. Secondly, more research papers and journal articles could be researched or reviewed. Therefore, the findings of this paper cannot be widely generalized. The findings of this research paper could encourage researchers and managers to conduct more research for addressing impact of supply chain integration on business performance and its challenges.
\end{abstract}

Keywords: Supply Chain Integration; Supply Chain Management; Operations Management; Logistics Management

\section{INTRODUCTION}

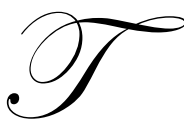

he integration of technology, people, business and processes is crucial for survival and competitive edge in the current digital age and this is not important only within a firm but also across extended enterprises (Awad \& Nassar, 2010a). Supply chain management is one of the most strategic functions of an organization which can be exploited to gain a sustainable competitive advantage in the marketplace. The revolutions in technology and business practices have also brought a revolution in the world of supply chain management by organizations (Handfield \& Nichols, 1999). The most prominent example of such revolution is the supply chain management of Wal-Mart Inc. (Lummus \& Vokurka, 1999). This evolution in technology and business practices have enabled different strategic and channel members (Suppliers, Manufacturers, Wholesalers, and Retailers) to gain a sustainable competitive advantage in the marketplace as a chain by integrating their supply chain management system to trade goods/services and to share information efficiently (Cooper, Lambert, \& Pagh, 1997). The above integration in supply chain management is supposed to increase the business performance of an organization in the marketplace. It is also argued that integration of supply chain management system of organizations has enabled organizations to decrease their costs and to increase customer satisfaction by satisfying customer needs with diversified goods and services (Fawcett \& Magnan, 2002). 
It is important now for corporations to search for new business paradigms to gain a sustainable competitive advantage in the marketplace. There are different examples available such as Total Quality Management (TQM), Theory of Constraints (TOC), Supply chain management practices adopted by corporations for cutting costs, increasing performances, and beating the competition. Information is now a competitive advantage as well as a "challenge" for corporations in the marketplace. Information has enabled firms to reengineer activities and practices for being competitive in the marketplace. The above revolutions have led to supply chain integration among channel partners where supply chain consists of all the processes directly or indirectly involved in providing solutions to customer problems by firms. A supply chain of an organization includes manufacturer, supplier, and channel intermediaries like wholesalers/retailers. (Awad \& Nassar, 2010a)

Today, firms tend to integrate their supply chain systems with the channel partners to increase performance. Awad \& Nassar (2010a) claimed that the developments in supply chain management in the form of supply chain integration had not only offered the potential to reduce costs but also to increase revenues, profits and performance of the firms. But he also stated that there were some challenges associated with the integration of supply chain management by the channel members. It was also argued in the paper of Awad \& Nassar (2010a) that the most significant form of supply chain integration was information sharing.

In this paper, the impact of supply chain integration on business performance and the challenges associated with supply chain integration are assessed and analyzed. This paper is divided in six main sections. The first section has provided an introduction to the paper. The second section presents and discusses the literature review regarding supply chain integration, its impact on business performance and the challenges associated with supply chain integration. The third section discusses research methodology and the fourth section analyzes the topic by conducting a theoretical critical analysis and critical review of different research papers and articles about supply chain integration, its challenges and its impact on the business performance. The fifth section summarizes the discussion analyzed and presented in the third section and it is followed by the sixth and final section that concludes the paper.

\section{LITERATURE REVIEW}

The concept of supply chain management was first introduced in 1980s (Oliver \& Webber, 1982). Supply chain management has been considered as one of the most popular concepts of management in general (La Londe, 1997) and the most popular concepts of logistics in particular (Ross, 1998). There are several different definitions for supply chain related to integration (Mentzer, et al., 2001) such as "the concept of supply chain management is all about integration" (Pagell, 2004). Integration of supply chain management is considered to be strategic as well as important for operational excellence (Bechtel \& Jayaram, 1997; Christopher, 1997; Lambert, Cooper, \& Pagh, 1998; Frohlich \& Westbrook, 2001; Zailani \& Rajagopal, 2005). It has been proved through research and practice that more integration of supply chain leads to better performance (Stock, Greis, \& Kasarda, 2000; Droge, Jayaram, \& Vickery, 2004; Gimenez \& Ventura, 2003). It has also been argued by Cagliano, Caniato, \& Spina (2006) that there is a positive impact of supply chain integration on the business performance.

Talking specifically, Trkman \& Groznik (2006) described different benefits of supply chain integration. They stated that supply chain integration enhances the process of information sharing within the organization and outside the organization (suppliers, channel partners, customers and other stakeholders). They further argued that information technology had made it possible for organizations to integrate their supply chains while it was also an advantage in terms of cost because information technology solutions for any business process were always cost effective. Therefore, supply chain integration decreased the costs. They recommended that information technology must be effectively utilize in the supply chain integration to enhance the process of information sharing and cost reduction for gaining a sustainable competitive advantage in the marketplace. Trkman \& Groznik (2006) also discussed certain other benefits of supply chain integration as it enabled the organization to do effective business renovation and business process modeling that increased the efficiency and profitablity of a business. Different benefits of supply chain integration were also presented by several other researchers. Li, Ragu-Nathan, RaguNathan, \& Rao (2006) stated that supply chain integration enabled the organization to gain a sustainable competitive advantage in the marketplace and it enhances organizational performance by enabling it to reach its goals and objectives effectively and efficiently. Rosenzweig, Roth, \& Jr. (2003) state that supply chain integration enables an 
organization to satisfy the needs and wants of target customers "superiorly" relative to competition and thus customer satisfaction/loyalty increases. This provides a sustainable competitive advantage to the organization. Vickery, Jayaram, Droge, \& Calantone (2003) explained that supply chain integration enhanced the financial performance of an organization. They further exclaimed that supply chain integration improved the financial ratios such as returns on assets, return or equity and working capital ratio etc. because it directly impacted the sales. Sales were increased because the firm was in a position to satisfy the needs and wants of customers superiorly and increased customer loyalty boosted sales revenues. As customer satisfaction and loyalty increased, customer recommended the product to other customers and thus sales were increased. As a result, the firm performed well financially because of supply chain integration. The same benefits and impacts of supply chain integration on business performance were explained by Gunasekaran, Patel, \& McGaughey (2004), Petersen, Handfield, \& Ragatz (2005), Stank, Keller, \& Closs (2001) and Simatupang, Wright, \& Sridharan (2002). The following figure summarizes the benefits associated with supply chain integration:

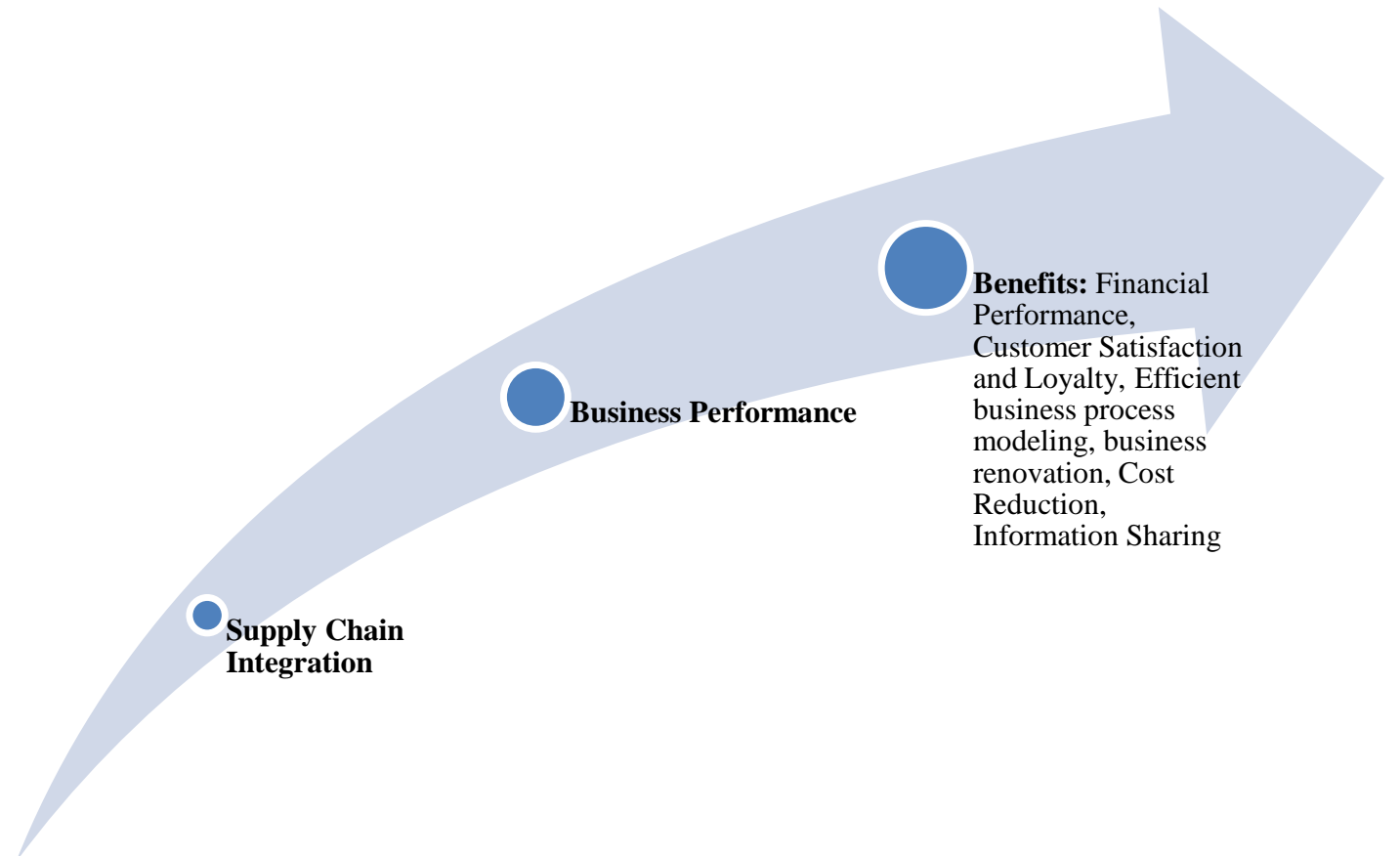

Figure 1: Impact of supply chain integration on business performance in terms of benefits.

There were also certain challenges explained by Awad \& Nassar (2010a) and Awad \& Nassar (2010b) but their details will come in the methodology section. These challenges were: (1) it was essential for an organization to consider supply chain integration strategy as an essential component of business only if it could relate it to its strategy theory and concepts, (2) customer order management was a tough challenge because different value chain partners integrated their supply chains to satisfy the needs and wants of their customers "differently" from competitors for gaining a sustainable competitive advantage, (3) Logistics management could cause several challenges for firm integrating their supply chain because differnet value chain partners had different supply chain or value chain structures with different organizational cultures, (4) Operations flexibility also became a challenge due to organizational differences when firms wanted to integrate and colloborate, (5) it was difficult to maintain standards in case of organizational differences while integrating supply chains such as size, culture, structure and people etc., (6) procurement management became difficult, (7) It was difficult to integrate two organizations having different values, visions, missions, cutlures, leaderships, and structures etc, (8) application integration was very difficult because of different Enterprise resource planning (ERP) systems adopted by organizations, (9) there were certain extranet adapting challenges, (10) it was not easy to integrate different business processes at different organizations, (11) Culture and Change Management themselves became a challenge for organizations, (12) supplier competence requirements were important to consider, (13) the process of data and information integration was 
complex and complicated, and (14) the forces of globalization and commoditization were not stoppable and they could impact supply chain integration decisions.

\section{METHODOLOGY}

\section{Research Design}

It is important to note that the methodology selected from research is secondary research. Different journal articles and research papers (preference will be given to papers having empirical proofs that supply chain integration has a positive impact on business performance) will be presented in this paper and, in the next section, they will be critically analyzed by making a comparative analysis with the research papers that opposed this view that supply chain integration leaded to better business performance.

\section{Sample}

A sample of 21 research papers has been selected in the analysis/findings section and discussion section to discuss the impact of supply chain integration on business performance and the challenges associated with the integration of supply chain among different channel partners. The time period of 1995-2011 has been selected and the journal articles/research papers were selected that were published within this period. These journal articles were selected from different journals such as:

1. The international journal of logistics management

2. International journal of logistics

3. International journal of production and operations management

4. Journal of operations management

5. International journal of physical distribution and logistics Management

6. International journal of production economics

7. Supply chain management review

8. Journal of business logistics

9. Supply chain management: An international journal

10. Business process management journal

11. Transportation journal

\section{ANALYSIS AND FINDINGS}

\section{Impact of supply chain integration on business performance}

Frohlich \& Westbrook (2001) conducted an empirical study to measure the impact of supply chain integration on performance of firms. A sample of 322 manufacturers was taken from across the globe to study their supply chain management systems. Different scales were developed to measure supply chain integration of these manufacturers. Five different strategies for supply chain integration were identified and it is important to note that each of the strategies was characterized by an "Arc of integration" which represented the direction towards suppliers or customers and also the degree of integration activity. A hypothesis was generated which was "Companies with greatest arcs of supplier and customer integration will have the largest rates of performance improvement".

The findings of empirical research study, by Frohlich \& Westbrook (2001), have two conclusions based on analysis. First, different supply chain management integration strategies were followed by different manufacturers across the world. These strategies could be classified in five different types and these types were defined by direction and degree of integration. These strategies were inward, periphery, supplier, customer, and outward facing. Second, it was concluded that higher degree of supply chain integration leads to higher levels of performance. The most significant characteristic of this research study is that it is the most prominent achievement and an empirical proof of the claim that supply chain integration leaded to better business performance and it was the one of the most prominent empirical studies to justify that high degree of supply chain integration led to high performance. The study revealed that all upward (towards supplier) and downward (towards customers), inward, periphery and 
outward facing supply chain integration was important and played a significant part in improving performance of firms. This study revealed that "Vertical Integration" was not always necessary to gain a sustainable competitive advantage in the marketplace and supply chain integration was more effective and efficient than vertical integration. (Frohlich \& Westbrook, 2001)

Trkman \& Groznik (2006) argued that business renovation was the most effective tool for increasing business performance to gain a sustainable competitive advantage. For business renovation, effective utilization and business process modeling plays an important role in the form of supply chain integration projects. Moreover, the business performance could be improved with the integration of various tiers in the supply chain. This paper also argues that the prerequisite for utilization of information and effective sharing is supply chain integration which enhances business renovation and thus improves performance of the business. The paper suggested a simulation based methodology to measure the benefits of supply chain integration. A case study of procurement process of a petrol company was mentioned by Trkman \& Groznik (2006) to indicate the process that supply chain integration improved business performance. In short, this study strongly encouraged the process of supply chain integration and stressed that supply chain integration always led to high levels of performance.

Grean \& Shaw (No Date) mentioned and discussed a case of Wal-Mart and Procter \& Gamble to prove that supply chain integration always led to better performance. In his paper, he described the incident of channel partnership between Wal-Mart (A retailer) and Procter \& Gamble (A manufacturer). Both the firms are the major players in their respective industries. Both the firms identified, developed and adopted an effective and efficient way to share information to leverage information technology by sharing data across their supply chain systems. Due to better coordination because of supply chain integration, the processes of both the firms became efficient leading to better performance. Costs were reduced for both the firms as there was reduced needs for storing inventories and this supply chain integration also enhanced their sales and revenues. Customer focus of both the organizations was strengthened which increased customer loyalty and profitability for both the organizations. The paper indicated that supply chain integration was mutually beneficial to all the channel parties instead of so called "fight of value pie" among organizations (vertical integration is a fight of capturing the value pie at the expense of others channel partners). This process of increasing business performance by integrating supply chain management system is an effective and efficient tool that must be adopted by organizations to gain a sustainable competitive advantage in the marketplace. (Grean \& Shaw, No Date)

Another research study was conducted by Zailani \& Rajagopal (2005) to discover the impact of supply chain integration on performance. This article was important because it studied and made a comparative analysis of US and East Asian companies to investigate supplier and customer integration for increasing business performance. The research methodology included three phases. In the first phase, 30 research articles were selected related to supply chain concepts and practices. In the second phase, the focus was narrowed by directing investigations to articles related to US and East Asian companies only. In the third phase, a comparative analysis of supply chain integration for increasing performance between US and East Asian companies was conducted. This study again justified the claim that supply chain integration among different channel partners in US and East Asian Countries leaded to better business performance. It was also identified in the paper that markets were dynamic and needs and wants of people were changing dramatically. The supply chain management and its integration among different channel partners enabled the organization to meet the challenges of changing business environment and it provided them an opportunity to meet the needs and wants of customers effectively and efficiently. The potential benefits of supply chain integration to meet modern business challenges could not be ignored. This potential could be maximized only if the interrelationships in the different areas or parts of supply chain were identified and goals of all the channel partners should be aligned efficiently to meet the competitive objectives of all the supply chain partners. (Zailani \& Rajagopal, 2005)

A paper, presented by Fabbe-Costes \& Jahre (2008), analyzed the different research papers and articles which stated that supply chain integration led to better performance and it also presented articles that negated this view held about supply chain integration. Nine important journals related to logistics, supply chain and operations management during the period 2000-2006 were selected for conducting study to evaluate the role of supply chain integration for better performance. 38 papers were selected and the topic was discussed by designing and implementing a multidimensional framework to select papers. It was found that supply chain integration did not 
always lead to better performance. It was summarized that it could not be concluded from the literature that supply chain integration always led to better performance. It was claimed in the paper of Fabbe-Costes \& Jahre (2008) that this paper presented the view of both sides of the argument about the impact of supply chain integration on business performance by conducting an empirical research and compilation of research papers.

\section{Challenges}

Awad \& Nassar (2010b) explained that neither it was easy to integrate the supply chain strategies among organizations and nor it was easy to integrate the supply chain strategy of an organization with its corporate strategy. They further explained that supply chain integration had became the top concern of top management levels as there was an increasing awareness among organizations that supply chain was the lifeblood an organization. Different multinational organizations could gain a sustainable competitive advantage internationally if they could integrate their supply chain management in different regions and boundaries. It was because supply chain integration enabled knowledge sharing and innovation across the organization and it enabled the organization to manage uncertainty expected in different geographical boundaries caused by the diverse international political, economic, social and technological contexts.

Awad \& Nassar (2010b) further argued that the challenges associated with supply chain integration could be described from three perspectives such as: technical perspective, managerial perspective and relationship perspective. The following figure represents the different kinds of challenges that were presented in the paper. It summarizes the business micro-environmental challenges, business macro-environmental challenges and technical challenges. This paper provided a strategic view of the business challenges associated with supply chain integration and these challenges were never presented before so prominently in any other research paper or article. This fact weakens the claim that supply chain integration leaded to better business performance because how one could argue on the positive impact of supply chain integration on business performance if they do not know about the challenges associated with it. This identifies an opportunity to researchers to explore these challenges more. The following figure identifies some of the challenges associated with supply chain integration:

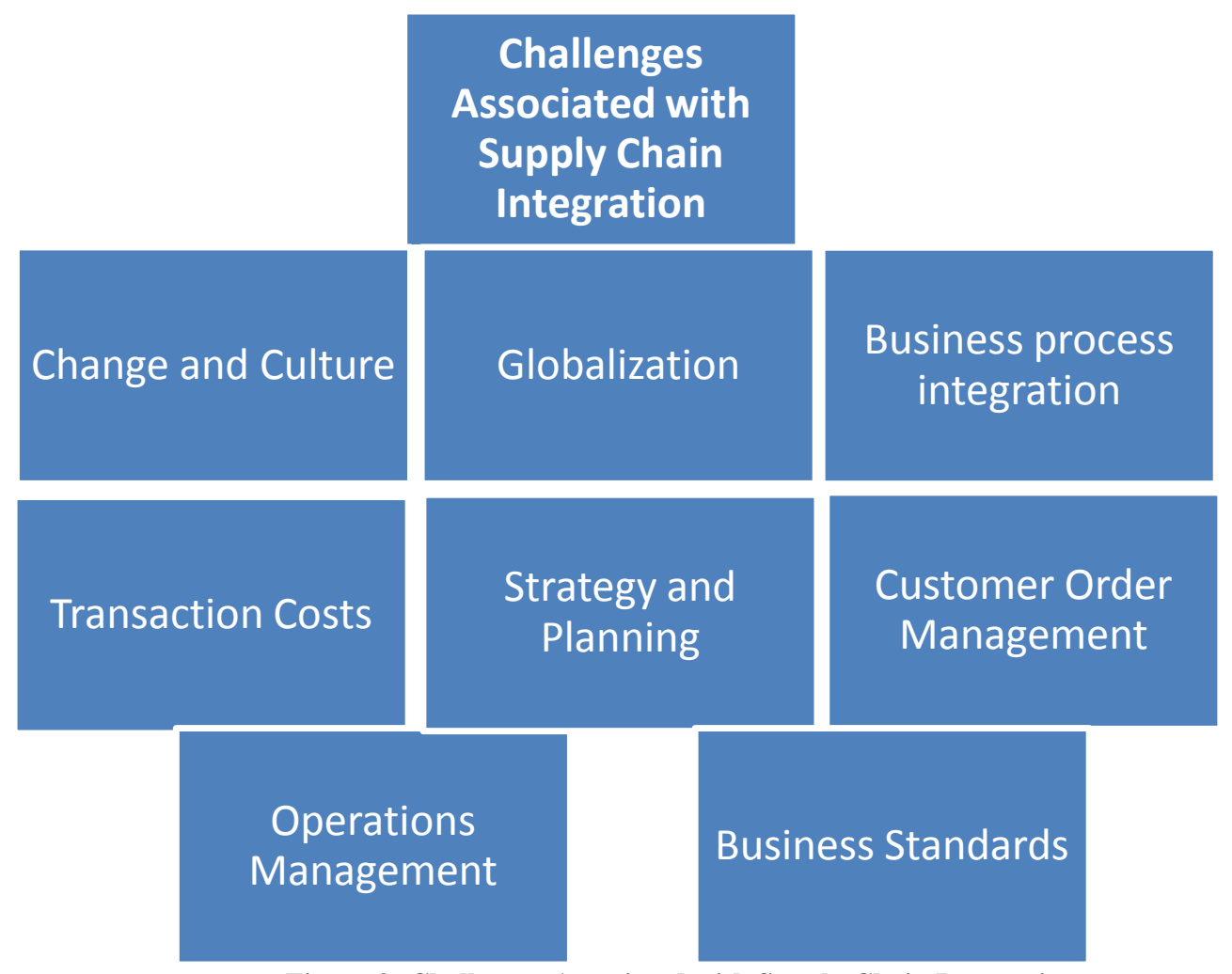

Figure 2: Challenges Associated with Supply Chain Integration 
The different challenges that were associated with the supply chain integration are as follows:

\section{Change and Culture}

Karkkainen \& Ala-risku (2003) argued that each and every organization had an organizational culture that defined its values, mission, structure and strategy. Organizational culture was unique for every organization. The most difficult challenge that confronts the corporations is the culture and change because culture defines the relationships within an organization such as relationships among suppliers, customers, employees and other stakeholders. Therefore, an organization might need a cultural change to integrate its supply chain strategy with another organization. Cultural change is not an easy task at it changes everything such as values, mission, structure, strategy and relationships and it the biggest challenge faced by organizations while integrating their supply chains (Cited in Awad \& Nassar, 2010b).

\section{Globalization}

Awad \& Nassar (2010b) argued that world markets were moving towards globalization and commoditization. Therefore, different challenges were raised by these factors as it became difficult for organizations to cut costs and integrate their business processes internationally. They further stated that companies look for new markets and production processes during the industrial age but now they looked for economies of scale. It was difficult for organizations to rely solely on supply chain integration to cut costs and it was not easy to integrate different supply chains systems globally or internationally. Thus, globalization is another challenge for supply chain integration.

\section{Business process integration}

Awad \& Nassar (2010b) argued that there was an need to coordinate business processes in such a way that they should improve performance and service. They further exclaimed that the modern e-commerce practices had enabled the organizations to link their internal processes with those of external stakeholders. But, there were certain compatability challenges among organizations such as technical, operational, strategic and political/legal challenges that could become an obstacle in business process integration among different organizations.

\section{Transaction costs}

Awad \& Nassar (2010b) described that integration of supply chain sometimes required outsourcing of certain activities that would involve uncertainty and risk (such as revelation of trade secrets and performance breakdowns). There is a transaction cost involved in outsourcing certain activities. These transaction costs could become a challenge for supply chain integration.

\section{Strategy and Planning}

McDermott \& Chan (1996) argued that strategy and planning itself became a challenge for supply chain integration among different organizations. It was because different organizations had different organizational or corporate objectives for which they strategize and plan. Supply chain strategy of an organization is integrated with its corporate strategy to reach its corporate goals and objectives. Thus, supply chain integration means integration of corporate strategies among differnet organizations which is a challenge because corporate goals and objectives of different organizations are different and unique. It is not easy or possible to integrate corporate strategies of two different organizations. (Cited in Awad \& Nassar, 2010b)

\section{Customer order management}

Boxall (1992) explained that customers were becoming more demanding and their needs and wants had changed in the modern world. Needs and wants of customers had become dynamic as well as diverse. The basic purpose of supply chain strategy was to identify and satisfy the needs and wants of customers effectively and efficiently. But, when needs and wants are changing, it was not possible to integrate supply chains for a longer 
period of time as market dynamics used to change rapidly. Therefore, it seems that supply chain integration was a short term orientation. (Cited in Awad \& Nassar, 2010b)

\section{Operations Management}

Awad \& Nassar (2010b) different operations' strategies were employed by different organizations to satisfy the needs and wants of target customers. Supply chain was a part of operations strategy. Another challenge for supply chain integration arises in operations as it is important for different organizations to integrate their supply chain management only if their operations are flexible enough to allow this integration.

\section{Business standards}

Finally, business or trade standards for operating in different industries are different. Sometime, the value chain for a specific product or service is scattered across different industries. Therefore, in such case, it becomes difficult to integrate supply chains because of the difference in industry or business standards. (Awad \& Nassar, 2010b)

\section{DISCUSSION}

In the previous findings from different journal articles and research papers, it is discovered that impact of supply chain integration "mostly" have a positive impact on business and it enhances business performance in terms of profitability, financial stability, customers' satisfaction and, at the top of all, accomplishment of business goals and objectives. These papers included empirical evidence from the literature and research that supply chain integration always leaded to better business performance. It was also important to note that no research paper described the challenges that were associated with supply chain integration and only Awad \& Nassar (2010b) defined those challenges in their research paper. The author was unable to find any research paper from the above research journals addressing challenges associated with supply chain integration. Therefore, he discussed only one research paper while describing challenges associated with integrating supply chains. This identifies a research gap and it also identifies a weak point in the argument that supply chain integration always leaded to better business performance which cannot be justified until or unless the challenges and factors affecting supply chain integration are effectively researched and analyzed. The author plans to conduct an empirical primary research on these challenges in his future research as these were not addressed efficiently in the previous research papers and journal articles. It is interesting to note that there are certain researchers who strongly oppose this view that supply chain integration leads to better business performance. The research papers opposing this view are being presented in this discussion to gain insights about the both sides of the argument.

There are several other researchers who are a bit confused in relating supply chain integration with efficient business performance such as Power (2005) stated that literature and previous research did not have a clear evidence that supply chain integration always led to better business performance and still more research was required to justify this hypothesis. He further argued that there was a clear difference in benefits gained in business world and promised benefits in the literature. He concluded that this might be possible because the concept of supply chain integration was not clearly described and this concept needed to be understood more. Kahn \& Mentzer (1996) argued the concept of supply chain integration was vague because there was no clear definition of supply chain integration in the literature. They further stated that if a concept was not clearly defined then how could one argue that supply chain integration led to better business performance. Pagell (2004) also stated that integration was defined in several different ways and there was no single/formation definition of this concept. The concept of supply chain integration and its role is also questioned by several other others like Harland (1996), Christopher \& Juttner (2000), and Bask \& Juga (2001). While some other researchers argue that supply chain integration was an acceptable concept in the past but, in recent years, it is being started questioned (Hakansson \& Persson, 2004; Bagchi, Ha, Skjoett-Larsen, \& Soerensen, 2005; Jahre \& Fabbe-Costes, 2005; Gripsrud, Jahre, \& Persson, 2006).

The concern to analyze the impact of supply chain integration on business performance and their relationship is increasing among different researchers and authors. The need for empirical research in this area is acknowledged and lack of understanding in this area is considered as a critical problem by the researchers and 
managers (Stank, Keller, \& Closs, 2001; Wisner, 2003; Rodrigues, Stank, \& Lynch, 2004). Due to lack of understanding and empirical research in the area of supply chain integration and its impact on business performance, it is not easy to advise that how to integrate, what to integrate, what would be the cost of integration and what are the consequences (negative impact on innovation and agility) if supply chain integration goes wrong etc. In simple words, it is neither possible for researchers or managers to analyze the impact of supply chain integration on business performance nor they can conclude that supply chain integration leads to better performance. It is because of the lack of understanding and empirical research regarding supply chain integration and its impact on business performance. Secondly, the studies about the supply chain integration lacks reliability because, in case of lack of understanding or definitions of variables, because it is not possible to test models and hypothesis regarding supply chain integration and its impact on the business performance (Stank, Keller, \& Closs, 2001; Stuart, McCutcheon, Handfield, McLachlin, \& Samson, 2002; Min \& Menzer, 2004). Therefore, literature presents two viewpoints of supply chain integration and its impact on business performance. One group of researchers say that supply chain integration always led towards better business performance while the other group says that the theory of supply chain integration is not defined accurately and there is a need to develop more understanding as well conducting empirical research to understand supply chain integration and its impact on the business performance.

The following table represents the articles, their titles and year of publishing to provide an overview of the analysis, findings and discussion.

Table 1: Summary of Analysis/findings and discussion

\begin{tabular}{|c|c|c|c|c|}
\hline & Author (s) & Title & Year & Contents \\
\hline 1 & $\begin{array}{l}\text { Frohlich \& } \\
\text { Westbrook }\end{array}$ & $\begin{array}{l}\text { Arcs of integration: an } \\
\text { international study of supply } \\
\text { chain strategies }\end{array}$ & 2001 & $\begin{array}{l}\text { Empirically claimed that supply chain integration led } \\
\text { to better business performance. }\end{array}$ \\
\hline 2 & $\begin{array}{l}\text { Trkman \& } \\
\text { Groznik }\end{array}$ & $\begin{array}{l}\text { Measurement of Supply chain } \\
\text { integration benefits }\end{array}$ & 2006 & Described the benefits of supply chain integration. \\
\hline 3 & Grean \& Shaw & $\begin{array}{l}\text { Supply Chain Integration } \\
\text { through information sharing: } \\
\text { Channel Partnership between } \\
\text { Wal-Mart and Procter \& } \\
\text { Gamble }\end{array}$ & $\begin{array}{l}\text { Date not } \\
\text { found }\end{array}$ & $\begin{array}{l}\text { Concluded that supply chain integration led to } \\
\text { effective and efficient information sharing by } \\
\text { discussing a case evidence of channel partnership } \\
\text { between Wal-Mart and Procter \& Gamble }\end{array}$ \\
\hline 4 & $\begin{array}{l}\text { Zailani \& } \\
\text { Rajagopal }\end{array}$ & $\begin{array}{l}\text { Supply chain integration and } \\
\text { performance: US versus East } \\
\text { Asian companies }\end{array}$ & 2005 & $\begin{array}{l}\text { Concluded that supply chain integration enabled the } \\
\text { organizations to perform well by conducting a } \\
\text { comparative analysis of US and East Asia. }\end{array}$ \\
\hline 5 & $\begin{array}{l}\text { Fabbe-Costes \& } \\
\text { Jahre }\end{array}$ & $\begin{array}{l}\text { Supply chain integration and } \\
\text { performance: a review of the } \\
\text { evidence }\end{array}$ & 2008 & $\begin{array}{l}\text { Compiled and analyzed views in favor and against the } \\
\text { claim that supply chain integration led to better } \\
\text { business performance }\end{array}$ \\
\hline 6 & Awad \& Nassar & $\begin{array}{l}\text { A Broader view of the Supply } \\
\text { Chain Integration Challenges }\end{array}$ & 2010 & $\begin{array}{l}\text { Discussed the different challenges associated with } \\
\text { supply chain integration. It was the first paper that } \\
\text { prominently addressed the challenges }\end{array}$ \\
\hline 7 & Power & $\begin{array}{l}\text { Supply chain management } \\
\text { integration and } \\
\text { implementation: a literature } \\
\text { review }\end{array}$ & 2005 & $\begin{array}{l}\text { Negated the view the supply chain integration led to } \\
\text { better business performance by presenting literature }\end{array}$ \\
\hline 8 & Kahn \& Mentzer & $\begin{array}{l}\text { Logistics and } \\
\text { interdepartmental integration }\end{array}$ & 1996 & $\begin{array}{l}\text { Claimed that the supply chain integration concept was } \\
\text { vague }\end{array}$ \\
\hline 9 & Pagell & $\begin{array}{l}\text { Understanding the factors that } \\
\text { enable and inhibit the } \\
\text { integration of operations, } \\
\text { purchasing and logistics }\end{array}$ & 2004 & $\begin{array}{l}\text { Stated that the concept of supply chain integration was } \\
\text { not well defined or effectively addressed }\end{array}$ \\
\hline 10 & Harland & $\begin{array}{l}\text { Supply chain management: } \\
\text { relationships, chains and } \\
\text { networks }\end{array}$ & 1996 & $\begin{array}{l}\text { Critically questioned the concept of supply chain } \\
\text { integration and its impact on business performance }\end{array}$ \\
\hline 11 & $\begin{array}{l}\text { Christopher \& } \\
\text { Juttner }\end{array}$ & $\begin{array}{l}\text { Supply chain relationships: } \\
\text { making the transition to closer } \\
\text { integration }\end{array}$ & 2000 & $\begin{array}{l}\text { Analyzed that supply chain integration did not lead to } \\
\text { better business performance }\end{array}$ \\
\hline
\end{tabular}


Table 1: continued

\begin{tabular}{|c|c|c|c|c|}
\hline & Author (s) & Title & Year & Contents \\
\hline 12 & Bask \& Juga & $\begin{array}{l}\text { Semi-integrated supply } \\
\text { chains: towards the new era of } \\
\text { supply chain management }\end{array}$ & 2001 & $\begin{array}{l}\text { Concluded that supply chain integration might also } \\
\text { cause performance breakdowns }\end{array}$ \\
\hline 13 & $\begin{array}{l}\text { Hakansson \& } \\
\text { Persson }\end{array}$ & $\begin{array}{l}\text { Supply chain management: } \\
\text { the logic of supply chains and } \\
\text { networks }\end{array}$ & 2004 & $\begin{array}{l}\text { Claimed that supply chain integration was useful in } \\
\text { the past but not now }\end{array}$ \\
\hline 14 & $\begin{array}{l}\text { Bagchi, Ha, } \\
\text { Skjoett-Larsen, \& } \\
\text { Soerensen }\end{array}$ & $\begin{array}{l}\text { Supply chain integration: a } \\
\text { European survey }\end{array}$ & 2005 & $\begin{array}{l}\text { Conducted a research in Europe to justify that supply } \\
\text { chain integration was not a useful concept anymore }\end{array}$ \\
\hline 15 & $\begin{array}{l}\text { Jahre \& Fabbe- } \\
\text { Costes }\end{array}$ & $\begin{array}{l}\text { Adaptation and adaptability in } \\
\text { logistics networks }\end{array}$ & 2005 & $\begin{array}{l}\text { Claimed that supply chain integration should be } \\
\text { researched more before arguing on its importance for } \\
\text { business }\end{array}$ \\
\hline 16 & $\begin{array}{l}\text { Gripsrud, Jahre, } \\
\text { \& Persson }\end{array}$ & $\begin{array}{l}\text { Supply chain management - } \\
\text { back to the future? }\end{array}$ & 2006 & $\begin{array}{l}\text { Concluded that supply chain integration could not do } \\
\text { any good for business until it is properly researched or } \\
\text { defined by researchers or managers }\end{array}$ \\
\hline 17 & $\begin{array}{l}\text { Stank, Keller, \& } \\
\text { Closs }\end{array}$ & $\begin{array}{l}\text { Performance benefits of } \\
\text { supply chain logistical } \\
\text { integration }\end{array}$ & 2001 & $\begin{array}{l}\text { Proposed that the supply chain integration should be } \\
\text { explored more to understand its benefits }\end{array}$ \\
\hline 18 & Wisner & $\begin{array}{l}\text { A structural equation model of } \\
\text { supply chain management } \\
\text { strategies and firm } \\
\text { performance }\end{array}$ & 2003 & $\begin{array}{l}\text { Stated that the concern to explore supply chain } \\
\text { integration is increasing to understand its impact on } \\
\text { business performance }\end{array}$ \\
\hline 19 & $\begin{array}{l}\text { Rodrigues, Stank, } \\
\text { \& Lynch }\end{array}$ & $\begin{array}{l}\text { Linking strategy, structure, } \\
\text { process, and performance in } \\
\text { integrated logistics }\end{array}$ & 2004 & $\begin{array}{l}\text { Advised the supply chain integration must be focused } \\
\text { in research because it is not well defined and explored }\end{array}$ \\
\hline 20 & $\begin{array}{l}\text { Stuart, } \\
\text { McCutcheon, } \\
\text { Handfield, } \\
\text { McLachlin, \& } \\
\text { Samson }\end{array}$ & $\begin{array}{l}\text { Effective case research in } \\
\text { operations management: a } \\
\text { process perspective }\end{array}$ & 2002 & $\begin{array}{l}\text { Described that current hypotheses and models } \\
\text { regarding supply chain integration are weak and } \\
\text { inaccurate }\end{array}$ \\
\hline 21 & Min \& Menzer & $\begin{array}{l}\text { Developing and measuring } \\
\text { supply chain management } \\
\text { concepts }\end{array}$ & 2004 & $\begin{array}{l}\text { Claimed that more research was required to increase } \\
\text { the accuracy and reliability of supply chain integration } \\
\text { models }\end{array}$ \\
\hline
\end{tabular}

\section{CONCLUSION}

In this paper, supply chain integration's impact on business performance and the challenges associated with it were discussed and analyzed. The paper was divided in six main parts. The first part introduced the paper, defined supply chain integration and provided a brief overview of supply chain integration, its impact on business performance, its challenges and the paper. The second part discussed the concept of supply chain integration, its impact on business performance and the challenges associated with it the light of literature review. It was revealed that supply chain integration had a positive impact on business performance and it provided benefits to the business such as information sharing, cost effectiveness, sustainable competitive advantage, customers' satisfaction, business renovations, business process modeling and financial performance etc. This section also highlighted certain business challenges that were associated with supply chain management and its integration. The third section presented the research methodology as secondary research was selected and different research/papers and journal articles were selected to analyze the claim of the paper. The fourth section presented the analysis and findings by summarizing different research papers and articles that proved through empirical research studies that supply chain integration always led to better business performance. Different research papers were also reviewed to find challenges concerning supply chain integration but unfortunately little evidence and research was found that identified a research gap to be filled. Only one paper could be presented to discuss those challenges. The fifth section summarized the analysis and presented the counter view or counter argument held against the integration of supply chain management and its impact on business performance. 
It can be concluded from this discussion and analysis that the concept of supply chain integration is not efficiently explored and researched leaving certain gaps that should be filled with further research. More importantly, impact of supply chain integration on business performance as well as the challenges associated with it must be researched and explored at deeper levels. This research study has identified an important research gap because, without addressing and researching challenges associated with supply chain integration, it cannot be argued that supply chain integration led to better business performance or supply chain integration had a positive impact on business performance.

\section{AUTHOR INFORMATION}

Dr. Abdullah AlSagheer is an Assistant Professor of Management at the e-School of Quality and Business Management at the Hamdan Bin Mohammed e-University. He is teaching undergraduate courses level such as TQM Implementation, Capstone Project and graduate courses level such as Strategic Management of Innovation and Technological change, Innovation Strategies. He taught in several universities in USA. Also He worked in several firms in USA. Dr. AlSagheer has PhD in Education and Human Resource Studies specialized in Interdisciplinary Studies (Industrial and Human Recourse Management Engineering) and M.Ed Education and Human Resource Studies specialized in Interdisciplinary Studies (Industrial and Human Recourse Management Engineering) from Colorado State University (CSU). He received Master of Science in Electrical Engineering specialized in Integrated Systems \& Strategic Project Management. His undergraduate degrees were Bachelor of Science in Computer Engineering and a double major in Bachelor of Science in Electrical Engineering from California State University Long Beach (CSULB). Dr. AlSagheer research focuses in Strategic Management, Capstone Courses, Entrepreneurship and Leadership, Total Quality Management, Ergonomics and Human Factor Engineering, Performance Management, Curriculum Development, Human Resource Management, Management Training, Teamwork, Innovation Strategies, Engineering Management \& Industrial Engineering. E-mail: Dr.Abdullah_AlSagheer@yahoo.com

Maryam Ahli currently acquires the position of Graduate Manager in Etihad Airways. Ahli worked as Corporate Excellence Executive in Strategy and Corporate Excellence department in Dubai Women Establishment. Ahli holds a Bachelor of Business and Quality from Hamdan Bin Mohammed e-University. Ahli is a certified lead auditor of Quality Management System (QMS), Occupational Health and Safety (OHSAS), and Environment Management System (EMS) received from Lloyds -UK. Ahli experience varies from management systems designing (Quality, Occupational Health and Safety, Environment, Complaint Management, Business Continuity, IT and security management, social accountability and Corporate Social Responsibility), designing schemes for internal suggestions and complaints, designing and developing of policies and methodologies for organizational excellence (Criteria: Leadership, Policy and Strategy, People, Partnership and Resources, and Process), and performance management (People results, customer results, employee results \& organization results).

\section{REFERENCES}

1. Awad, H. A., \& Nassar, M. O. (2010a). Supply Chain Integration: Definition and Challenges. Retrieved September 1, 2011, from International Association of Engineers: http://www.iaeng.org/publication/IMECS2010/IMECS2010_pp405-409.pdf

2. Awad, H. A., \& Nassar, M. O. (2010b). A Broader view of the Supply Chain Integration Challenges. International Journal of Innovation, Management and Technology, 1 (1), 51-56.

3. Bagchi, P., Ha, B., Skjoett-Larsen, T., \& Soerensen, L. (2005). Supply chain integration: a European survey. The International Journal of Logistics Management , 16 (2), 275-294.

4. Bask, A., \& Juga, J. (2001). Semi-integrated supply chains: towards the new era of supply chain management. International Journal of Logistics , 3 (1), 5-23.

5. Bechtel, C., \& Jayaram, J. (1997). Supply chain management: a strategic perspective. The International Journal of Logistics Management , 8 (1), 15-34.

6. Boxall, P. F. (1992). Strategic human resource management: Beginning of a new theoretical sophistication? Human Resource Management Journal , 2 (3), 60-79. 
7. Cagliano, R., Caniato, F., \& Spina, G. (2006). The linkage between supply chain integration and manufacturing improvement programmes. International Journal of Operations \& Production Management, 26 (1), 283-299.

8. Christopher, M. (1997). Marketing Logistics. Oxford: Butterworth-Heinemann.

9. Christopher, M., \& Juttner, U. (2000). Supply chain relationships: making the transition to closer integration. International Journal of Logistics , 3 (1), 5-23.

10. Cooper, M. C., Lambert, D. M., \& Pagh, J. D. (1997). Supply Chain Management: More Than a New Name for Logistic. International Journal of Logistics Management , 8 (1), 1-14.

11. Droge, C., Jayaram, J., \& Vickery, S. (2004). The effect of internal versus external integration practices on time-based performance and overall firm performance. Journal of Operations Management , 22 (6), 557573.

12. Fabbe-Costes, N., \& Jahre, M. (2008). Supply chain integration and performance: a review of the evidence. The International Journal of Logistics , 19 (2), 130-154.

13. Fawcett, S. E., \& Magnan, G. M. (2002). The rhetoric and reality of supply chain integration. International Journal of Physical Distribution \& Logistics Management , 32 (5), 339-361.

14. Frohlich, M. T., \& Westbrook, R. (2001). Arcs of integration: an international study of supply chain strategies. Journal of Operations Management , 19, 185-200.

15. Gimenez, C., \& Ventura, E. (2003). Supply chain management as a competitive advantage in the Spanish grocery sector. The International Journal of Logistics Management , 14 (1), 77-88.

16. Grean, M., \& Shaw, M. J. (No Date). Supply Chain Integration through information sharing: Channel Partnership between Wal-Mart and Procter \& Gamble. Retrieved September 1, 2011, from University of Illinois at Urbana-Champaign: http://citebm.business.illinois.edu/it_cases/Graen-Shaw-PG.pdf

17. Gripsrud, G., Jahre, M., \& Persson, G. (2006). Supply chain management - back to the future? International Journal of Physical Distribution and Logistics Management , 36 (8), 643-659.

18. Gunasekaran, A., Patel, C., \& McGaughey, R. E. (2004). A framework for supply chain performance measurement. International Journal of Production Economics , 87 (3), 333-347.

19. Hakansson, H., \& Persson, G. (2004). Supply chain management: the logic of supply chains and networks. The International Journal of Logistics Management , 15 (1), 11-26.

20. Handfield, R. B., \& Nichols, E. L. (1999). Introduction to supply chain management. Upper Saddle River, New Jersey: Prentice Hall.

21. Harland, C. (1996). Supply chain management: relationships, chains and networks. British Journal of Management, 7, 63-80.

22. Jahre, M., \& Fabbe-Costes, N. (2005). Adaptation and adaptability in logistics networks. International Journal of Logistics: Research and Applications , 8 (2), 143-157.

23. Kahn, K., \& Mentzer, J. (1996). Logistics and interdepartmental integration. International Journal of Physical Distribution \& Logistics Management , 26 (8), 6-14.

24. Karkkainen, M., \& Ala-risku, T. (2003). Facilitating the Integration of SMEs to Supply Networks with Lean IT Solutions. The International Journal of Logistics Management , 8 (1), 88-93.

25. La Londe, B. (1997). Supply chain management: myth of reality? Supply Chain Management Review, 1, 67.

26. Lambert, D., Cooper, M., \& Pagh, J. (1998). Supply chain management: implementing issues and research opportunities. The International Journal of Logistics Management , 9 (2), 1-18.

27. Li, S., Ragu-Nathan, B., Ragu-Nathan, T., \& Rao, S. S. (2006). The impact of supply chain management practices on competitive advantage and organizational performance. Omega, 34 (2), 107-124.

28. Lummus, R. R., \& Vokurka, R. J. (1999). Defining supply chain management: a historical perspective and practical guidelines. Industrial Management \& Data Systems , 99 (1), 11-17.

29. McDermott, M., \& Chan, K. (1996). Flexible intelligent relationship management: the business success paradigm in a stakeholder society. Learning Organization , 3 (3), 5-17.

30. Mentzer, J., Dewitt, W., Keebler, J., Min, S., Nix, N., Smith, C., et al. (2001). Defining supply chain management. Journal of Business Logistics , 22 (2), 1-25.

31. Min, S., \& Menzer, J. (2004). Developing and measuring supply chain management concepts. Journal of Business Logistics , 25 (1), 63-99.

32. Oliver, R., \& Webber, M. (1982). Supply chain management: logistics catches up with strategy. In M. Christopher, Logistics: The Strategic Issues (pp. 63-75). London: Pitman. 
33. Pagell, M. (2004). Understanding the factors that enable and inhibit the integration of operations, purchasing and logistics. Journal of Operations Management , 22 (5), 459-487.

34. Petersen, K. J., Handfield, R. B., \& Ragatz, G. L. (2005). Supplier integration into new product development: coordinating product, process and supply chain design. Journal of Operations Management , 23 (3), 371-388.

35. Power, D. (2005). Supply chain management integration and implementation: a literature review. Supply Chain Management: An International Journal , 17 (1), 252-263.

36. Rodrigues, A., Stank, T., \& Lynch, D. (2004). Linking strategy, structure, process, and performance in integrated logistics. Journal of Business Logistics , 25 (2), 65-94.

37. Rosenzweig, E. D., Roth, A. V., \& Jr., J. W. (2003). The influence of an integration strategy on competitive capabilities and business performance: An exploratory study of consumer products manufacturers. Journal of Operations Management , 21 (4), 437-456.

38. $\quad$ Ross, D. (1998). Competing Through Supply Chain Management. New York, NY: Chapman \& Hall.

39. Simatupang, T. M., Wright, A. C., \& Sridharan, R. (2002). The knowledge of coordination for supply chain integration. Business Process Management Journal , 8 (3), 289-308.

40. Stank, T., Keller, S., \& Closs, D. (2001). Performance benefits of supply chain logistical integration. Transportation Journal , 41 (2), 32-46.

41. Stock, G., Greis, N., \& Kasarda, J. (2000). Enterprise logistics and supply chain structure: the role of fit. Journal of Operations Management, 18 (5), 531-547.

42. Stuart, I., McCutcheon, D., Handfield, R., McLachlin, R., \& Samson, D. (2002). Effective case research in operations management: a process perspective. Journal of Operations Management , 20 (5), 419-433.

43. Trkman, P., \& Groznik, A. (2006). Measurement of Supply chain integration benefits. Interdisciplinary Journal of Information, Knowledge, and Management , 1, 37-45.

44. Vickery, S. K., Jayaram, J., Droge, C., \& Calantone, R. (2003). The effects of an integrative supply chain strategy on customer service and financial performance: an analysis of direct versus indirect relationships. Journal of Operations Management , 21 (5), 523-539.

45. Wisner, J. (2003). A structural equation model of supply chain management strategies and firm performance. Journal of Business Logistics , 24 (1), 1-26.

46. Zailani, S., \& Rajagopal, P. (2005). Supply chain integration and performance: US versus East Asian companies. Supply Chain Management: An International Journal , 10 (5), 379-393. 


\section{NOTES}

